\title{
Effects of wind-induced sediment resuspension on distribution and morphological traits of aquatic weeds in shallow lakes
}

\author{
Vincent BERTRIN, * Sébastien BOUTRY, Gwilherm JAN, Greta DUCASSE, Florent GRIGOLETTO, Cristina RIBAUDO
}

Irstea, UR EABX - 50 avenue de Verdun, 33612 Cestas, France

*Corresponding author: vincent.bertrin@irstea.fr

\begin{abstract}
The spread of invasive aquatic plants (i.e., aquatic weeds) requires a broader knowledge of the factors determining their settlement at the lake scale, in order to improve management practices and biomonitoring. Among hydrodynamic pressures, wave action might influence submerged vegetation distribution in shallow lakes and potentially engender modifications of plant morphological traits. We here report a field survey conducted between 2014 and 2015 in French Atlantic Lakes to assess the spatial distribution and biomass production of two rooted aquatic weeds, Egeria densa Planch. and Lagarosiphon major (Ridl.) Moss, in relation to wind-induced sediment resuspension, water depth and sedimentary features. Moreover, we explored the relation between plant morphological traits and hydrodynamic disturbance under in situ conditions. At the lake scale, E. densa and L. major formed extensive monospecific stands, and occurred in the same areas only at low biomass. Both monospecific and mixed stands preferentially developed in shallow-sheltered or deep-exposed areas. Plant morphological traits showed different patterns in function of sediment resuspension according to the species and the lake. The influence of resuspension was however not systematic, with many cases where morphological traits were not affected at all. Maximum stem length appeared to be the most correlated trait towards sediment resuspension. Moreover, we found a significant correlation between the biomass and the sedimentary organic matter, indicating an interaction between the organic substrate preference of the plants and the effect of the canopy on fine particles sedimentation. On the whole, we highlighted the link between plant distribution, phenotypic plasticity and sediment resuspension, with calm-water zones favouring the settlement of dense vegetated stands. Our study could thus contribute to improve prediction models for identifying suitable areas for potential colonization by aquatic weeds. Further research is needed to better understand the role played by hydraulic forces in structuring the habitats in shallow lakes.
\end{abstract}

Key word: Exotic invasive hydrophytes; sedimentary organic matter; wind exposure; biomonitoring; colonization depth; alien plant management.

\section{INTRODUCTION}

Wave exposure is one of the abiotic factors influencing aquatic plant communities in freshwater ecosystems (Bornette and Puijalon, 2010 and references therein). Waves strongly affect the distribution of submerged macrophytes in shallow lakes, potentially driving to morphological damages on plant architectural features (Keddy, 1982; Strand et al., 1996; Riis and Hawes, 2003; Schutten et al., 2004). Water movement impacts on rooted aquatic plants depend on the magnitude of the hydraulic forces, the resistance capacity of the plants (i.e., root anchorage and stem breaking strength) and the sediment type (Schutten et al., 2005). For instance, mechanical stress directly shapes morphological features and biomass allocation. The plasticity in plant biomass (i.e., the root to shoot ratio, R:S), can be considered as an adaptation to physical disturbance (Chambers et al., 1991; BarratSegretain, 2001). Permanent exposure to water movement is able to disturb or alter plants development (Doyle, 2001), shoot elongation (Ellawala et al., 2011), branch length and branch number (Strand and Weisner, 2001), seedling and germination (Foote, 1988) and shoot density (Chambers et al., 1991). As a consequence, aquatic plants demonstrate capacities to morphologically adapt when they are confronted to hydrodynamic forces (Puijalon et al., 2008).

Waves may also exert indirect impacts on aquatic plants through sediment resuspension. Indeed, turbidity, associated to light attenuation, and depth gradient are structuring factors for rooted macrophytes distribution at intermediate depth (Lehmann et al., 1997). Submerged macrophytes distribution is then potentially limited by wave energy, with some species colonizing deeper parts of the lakes in order to avoid water mixing and sediment suspension caused by the orbital velocity of waves reaching the shoreline (Chambers, 1987). Waves are able to influence epiphytic growth, sediment grain size and water quality by water mixing, that selecting aquatic species according to their resistance against breakage (Koch, 2001; Bornette and Puijalon, 2010). On the other hand, the presence of dense vegetated mats can increase the sedimentation of fine particles and favor organic matter build-up (Madsen et al., 2001).

Hydrocharitaceae family gathers aquatic rooted macro- 
phytes, usually submerged, among which many species are considered as aquatic weeds. This is particularly the case for the two species Egeria densa Planch. and Lagarosiphon major (Ridl.) Moss, which occur in European freshwater ecosystems in both lentic and lotic waters (Dutartre et al., 1999; Celesti-Grapow et al., 2010; Hussner, 2012; Brundu, 2015). In natural ecosystems, they form large and dense stands causing important biogeochemical and management problems when climatic, hydromorphologic and trophic characteristics are advantageous for their development (Bini et al., 1999; Bini and Thomaz, 2005; Yarrow et al., 2009; Ribaudo et al., 2014). Light attenuation and fetch are among the most important variables determining the occurrence of the genus Egeria (Bini and Thomaz, 2005). Moreover, the onset of dense vegetated stands and the subsequent deposition of fine particles may significantly contribute to water clarity and improve light penetration (Madsen et al., 2001; Siffedine et al., 2011).

Several studies on the response of submerged plants to hydrodynamic forces have been carried out in mesocosms, whereas in situ conditions embed interactions with light, temperature and depth (Doyle, 2001; Sand-Jensen, 2003; Ellawala et al., 2011; Riis et al., 2012; Redektop et al., 2016). The investigation of wave exposure on aquatic weeds through field surveys is thus a key element for improving biomonitoring approaches in shallow lakes. Indeed, the integration of water depth, wind velocity and fetch in prediction models might help in detecting preferential habitats and physical thresholds for the spread of invasive macrophytes. In this study, we report the results of a survey conducted between 2014 and 2015 to assess the plant coverage and the biomass production of two rooted aquatic weeds, $E$. densa and $L$. major, in relation to sediment resuspension probability and sedimentary features. The objectives of the research were i) to obtain a quantitative assessment of aquatic weeds distribution and biomass in French Atlantic Lakes; ii) to evidence the dependence of plant distribution on sediment resuspension and water depth; and iii) to highlight the relation between morphological traits and physical disturbance within in situ conditions.

\section{METHODS}

\section{Study area}

French Atlantic Lakes (Carcans-Hourtin, Lacanau, Cazaux-Sanguinet and Parentis-Biscarrosse) are large shallow lakes located in the south-western coast of France, less than $5 \mathrm{~km}$ from the ocean (Fig. 1). These lakes were originated from the barrage of coastal rivers by littoral dunes (Tastet et al., 2008). The eastern bottom is characterized by a very gentle slope while the western bottom presents a steep slope at the dunes' foot. These four lakes are classified from oligo- to mesotrophic and constitute the southern distribution limit for isoetid lawns in Europe (Cellamare et al., 2012; Bertrin et al., 2013; Ribaudo et al., 2017). The main uses of these lakes are recreational activities such as boating, bathing, hunting and angling during a limited part of the year. Here, L. major appeared in Cazaux-Sanguinet in 1960, started to be signaled as a nuisance in late '70s and spread all over the four lakes in the following decades, showing a slow dynamic of invasion between 1985 and 2005 (Dutartre and Capdevielle, 1982; Bertrin et al., 2013). E. densa was not reported in the vegetation surveys of these lakes until 2006, and only two of them were concerned (Bertrin et al., 2013). Thanks to mild water temperatures $\left(>16^{\circ} \mathrm{C}\right.$ from April to October), the vegetative period of the two aquatic weeds is here extended during the year.

\section{Dense stands mapping and traits measurement}

In order to assess the dense stands boundaries of the two hydrophytes, vegetation surveys were carried out during the standing crop period (May-September) by echosounding, during 2014 in Carcans-Hourtin (HOU) and Lacanau (LAC) lakes and during 2015 in Cazaux-Sanguinet (CAZ) and Parentis-Biscarrosse (PAR) lakes. The scan sonar surveys were carried out on a boat equipped with a GPS coupled to a Humminbird 1197C. Transects were irregularly spaced along the lake's surface, according to the local bathymetry, and were concentrated along the shallowest areas of the lakes $(<5 \mathrm{~m})$, typically perpendicularly to the shoreline. Profiles were intensified when plant density was high; additionally, GPS points were marked in correspondence with the boundaries of each dense stand. Due to the presence of restricted areas for military purpose, in CAZ and PAR lakes some areas were not prospected by boat, but by feet. Concomitantly, plant collection was systematically carried out with a rake (harvested surface $=0.28 \mathrm{~m}^{2}$ ), every 200 to $500 \mathrm{~m}$, according to the local extension and homogeneity of the stands; in correspondence, a GPS point and the colonization depth was recorded. The operation was carried out by the same operator to minimize the error source (Johnson and Newman, 2011); plants were kept wet and refrigerated during the transport.

In laboratory, morphological traits and biomass were measured. For each shoot, maximal stem and root length $(\mathrm{cm})$, number of stems (stems shoot $\left.{ }^{-1}\right)$ and number of roots $\left(\right.$ roots shoot ${ }^{-1}$ ) were measured. For each sample, shoots were counted for estimating shoot density (shoots $\mathrm{m}^{-2}$ ). Finally, plants were sorted for above- (stems) and belowground (roots) parts and dried at $70^{\circ} \mathrm{C}$ for at least $72 \mathrm{~h}$ until stabilized dry weight. Total biomass was obtained by the sum of above- and belowground dry weight $\left(\mathrm{g}_{\mathrm{DW}} \mathrm{m}^{-2}\right.$ ); root to shoot ratio (R:S) was calculated as the ratio of the below- and aboveground dry weight. Also, 
additional data obtained along unpublished studies were included in the dataset for the comparison against sedimentary resuspension. Those data were collected at different seasons between late summer 2013 and late summer 2016 following the same protocol described above.

At the office, sonar recordings were read by Humminbird PC and transferred to a GIS system (ArcGIS 10.2 platform, 2017). Verification of the stand boundaries were made on each profile through the program HumViewer. Transects and GPS points were then geolocated and polygons were manually reconstructed to produce distribution maps. From biomass measurements, the mean biomass value $(3<n<5)$ was associated to each shape in the distribution map.

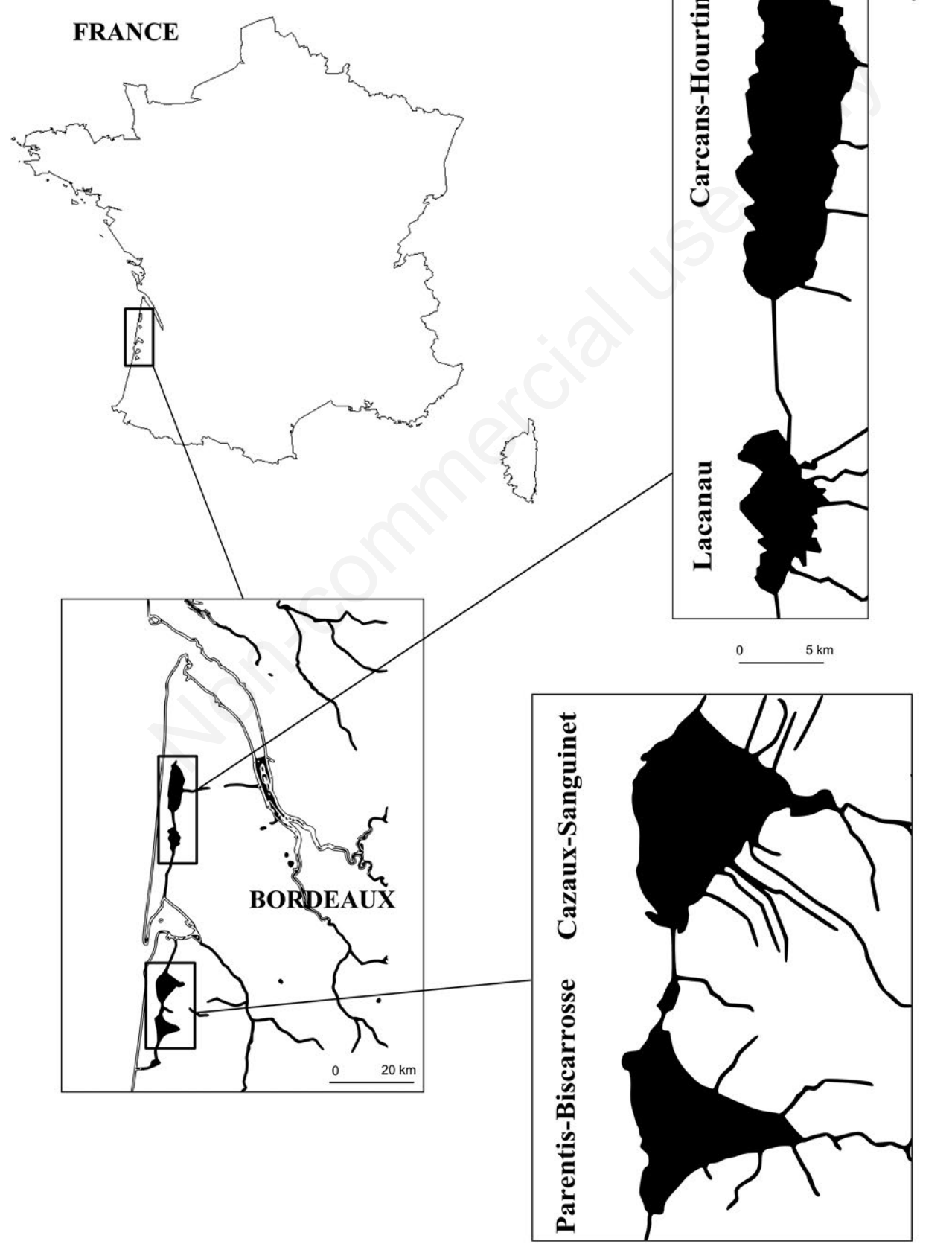

Fig. 1. Geographic location of French Atlantic Lakes. 


\section{Sediment characterization}

Concomitantly to biomass harvesting, sediment samples were collected by means of a Van Veen grabber (volume $=2.5 \mathrm{~L}$ ) and, after homogenization of the whole sample, transferred in triplicates into $40 \mathrm{~mL}$ plastic vials; samples were kept in a cooled box and immediately frozen at the laboratory. Several sediment samples were also collected in bare areas of the prospected shores. Analyses of sedimentary bulk density, porosity, water content and organic matter (OM) content were performed according to standard procedures, as described in Ribaudo et al. (2017).

\section{Bathymetry and sediment resuspension probability}

A rasterized georeferenced bathymetric map was provided by the Adour-Garonne Water Agency. Each openwater raster cell had a resolution of $10 \mathrm{~m}$. The probability of sediment resuspension was based on wind data collected at a weather station located in Cap-Ferret (443'ㄷ'N, $1^{\circ} 14^{\prime} 54^{\prime \prime} \mathrm{W}, 9 \mathrm{~m}$ above chart datum; wind measurement height above the ground: $10 \mathrm{~m}$ ). The velocity $\left(\mathrm{m} \mathrm{s}^{-1}\right)$ and direction $\left(^{\circ}\right)$ of the wind, averaged each 10 min, were available for this station. We used the maximum daily values of both parameters provided by the French climate normals (Météo France) obtained between November 2012 (one year before the first sampling campaign) and November 2016 (date of the last sampling campaign), for a total of 1451 days.

The wind is able to generate waves and currents depending on the water depth and the fetch (i.e., the length of open water without any obstacle in a distinct direction). Wave formation is therefore influenced by the size and the shape of the lake, as well as by its exposure to the prevailing winds (Keddy, 1982; Schutten et al., 2005). In this study, we calculated the fetch on the all grid cells for each wind compass direction (0-360 in 10-degree increments) as described in the U.S. Geological Survey Wind Fetch Model (Rohweder et al., 2012) with ArcGIS 10.2 platform. We also calculated the probability of sediment resuspension thanks to the Wave Model (Rohweder et al., 2012) with ArcGIS. This model calculates the maximum orbital wave velocity (um, expressed as $\mathrm{m} \mathrm{s}^{-1}$ ) using water depth from the bathymetric map and the calculated wave length, height and period as described below:

um $=\pi \times$ wave height $/$ (wave period $\times \sinh \times$ $(2 \pi \times$ water depth / wave length $))$

The maximum orbital wave velocity, as it depends on depth, expresses the vertical upward forces acting on the plants, through uprooting (Schutten et al., 2004). For each day and each grid cell, in which the orbital velocity creates sediment resuspension, is attributed the " 1 " value, whereas days with no sediment resuspension are classified as " 0 ". The model calculates the probability of having a sediment resuspension event during a temporal range for each individual raster cell. Therefore, the final unit of the model is a sediment resuspension probability $(0-100 \%)$ and is applied to $17 \times 17 \mathrm{~m}$ map grid cells.

\section{Statistics}

Linear regression was employed to test the dependence of the sedimentary OM on sediment resuspension, and the dependence of morphological traits on sediment resuspension probability and OM content. Pairwise t Student test was used to test differences in morphological traits between the two hydrophytes. Pearson correlation test was used to test the relationship between the biomass and the sedimentary OM content. Prior to analysis, all data were transformed as $\log (x+1)$. Analyses were performed using $\mathrm{R}$ Program (R Development Core Team, 2017).

\section{RESULTS}

Prevailing stronger winds between November 2012 and November 2016 blew from the west-northwest; they also came from the north-east but with a minor velocity (Fig. 2). The daily mean wind speed was mainly bounded from 5 to $20 \mathrm{~m} \mathrm{~s}^{-1}$ (maximum $26.8 \mathrm{~m} \mathrm{~s}^{-1}$, mean $9.1 \mathrm{~m} \mathrm{~s}^{-1}$ ) with only $0.3 \%$ of wind-exempted days during the whole investigation period. The resuspension probability reflected a huge range of wave exposure (Fig. 2), with the eastern part of lakes presenting a higher probability of sediment resuspension than the western part.

The distribution of sedimentary OM content varied according to the bathymetry of lakes (Fig. 2). Within each lake, an elevated spatial variability was observed, with fluffy sediments collected at the deep-sheltered bays and clear quartz sands at the shallow wind-exposed shores. On the whole, sedimentary features slightly varied across lakes' shores, with a sandy bottom characterized by a mean bulk density of $1.6 \pm 0.3 \mathrm{~g} \mathrm{~cm}^{-3}$ (range $0.9-2.3$ ), a porosity of $50 \pm 20 \%$ (20-98), a water content of $36.1 \pm 24.4 \%$ (13-93), and OM content of $9.8 \pm 18.5 \%$ as loss of ignition (LOI, 0.1-85.7) (overall $n=723$ ). Sedimentary OM was significantly dependent on the resuspension probability $\left(\mathrm{F}_{1,518}, \mathrm{R}^{2}=0.13, \mathrm{P}<0.001\right)$.

In 2014, a total of 21 and 82 sonar recordings were performed, for HOU and LAC lakes respectively. In 2015, a total of 41 and 35 sonar recordings were performed, for CAZ and PAR lakes respectively. Some lake areas were not prospected by echo-sounding because no dense stands were observed nearby during the field campaigns. As a consequence, low biomass values $\left(<50 \mathrm{~g}_{\mathrm{DW}} \mathrm{m}^{-2}\right)$, corresponding to sparse shoots, were not included in the distribution maps neither in the whole-lake biomass 

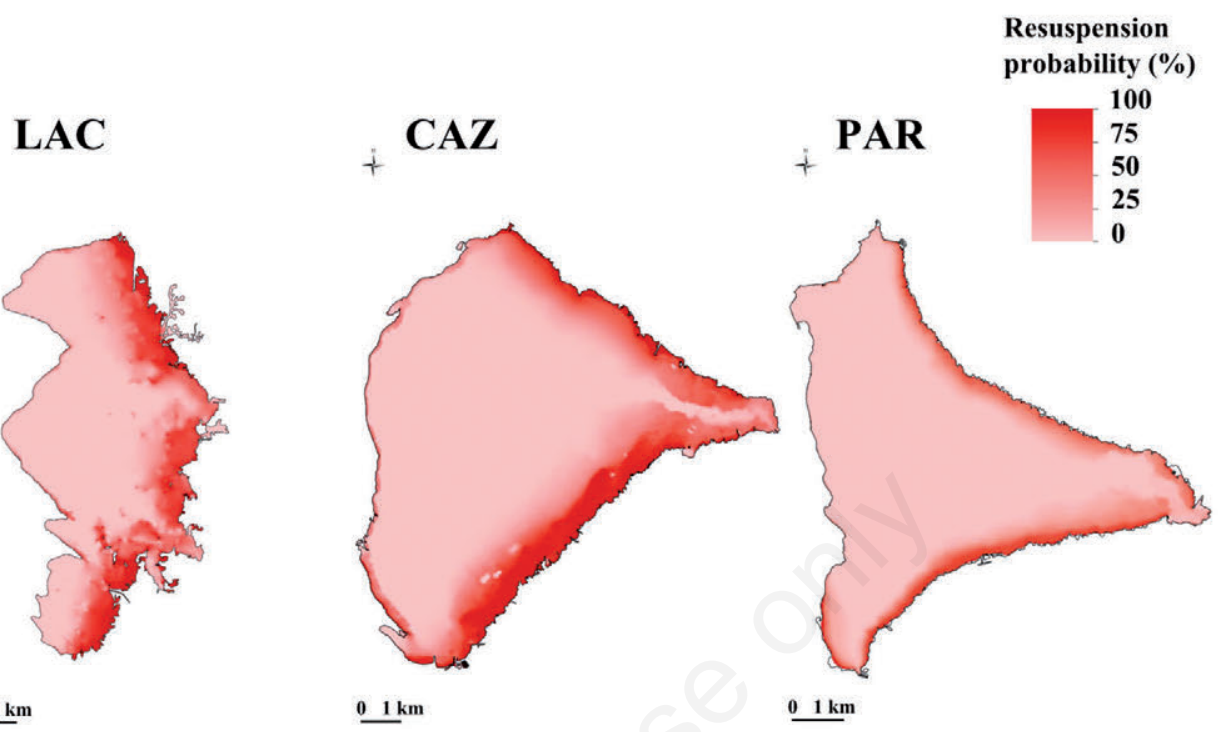

LAC

+ CAZ

+ PAR

robability (\%)

\section{HOU}
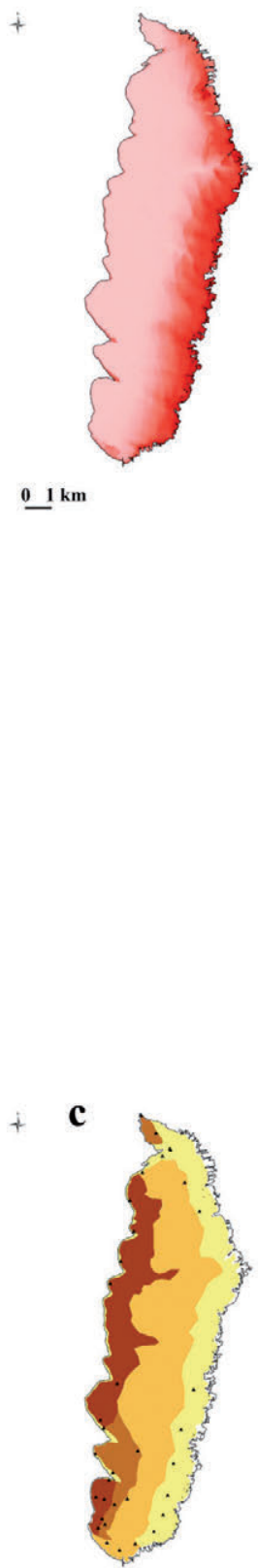

$\underline{0 \quad 1} \mathrm{~km}$

b

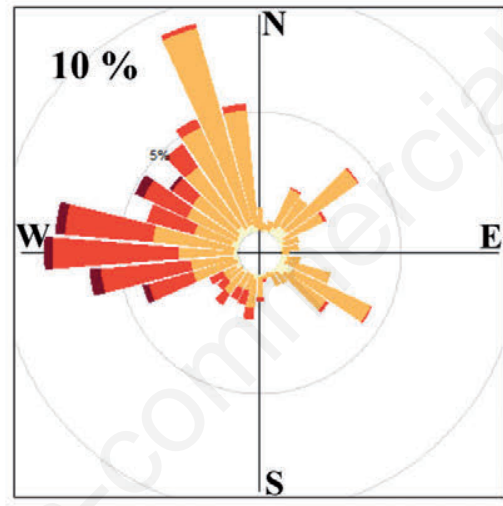

Wind speed $\left(\mathrm{m} \mathrm{s}^{-1}\right)$

$20-30$

$10-20$

5 - 10

$\mathbf{0}-\mathbf{5}$
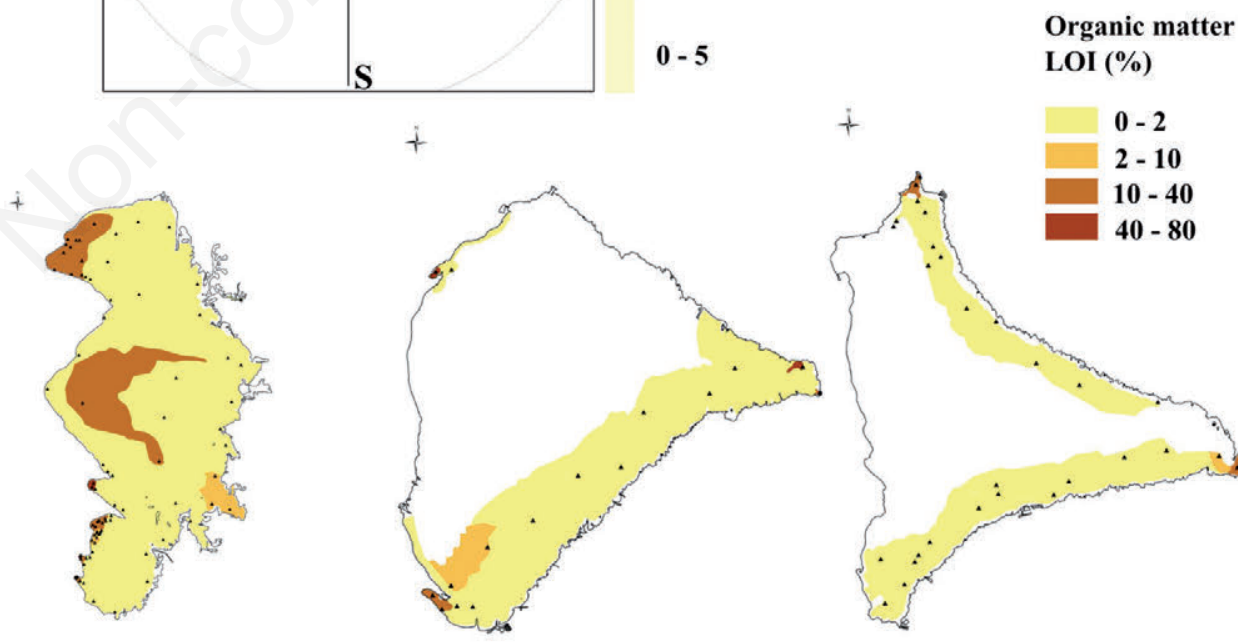

$10-40$

$40-80$

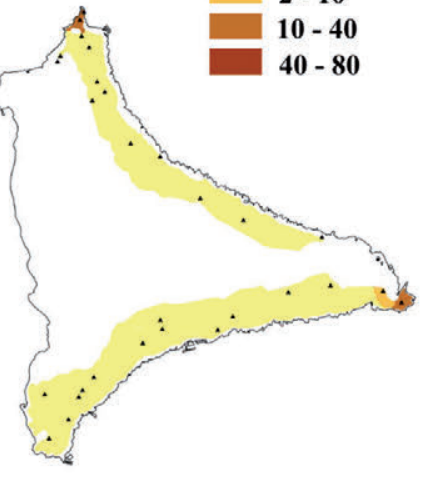

$0 \quad 1 \mathrm{~km}$

$\underline{01 \mathrm{~km}}$

$0 \quad 1 \mathrm{~km}$

LAC

PAR

Fig. 2. a) Sediment resuspension probability (0-100\%) calculated for the period November 2012-November 2016 in French Atlantic Lakes. b) Windrose elaborated from wind speed daily values for the period November 2012-November 2016. c) Organic matter maps of French Atlantic Lakes obtained in 2014 (HOU and LAC) and 2015 (CAZ and PAR). Triangles indicate sediment collection sites. 
assessment for precaution. Whole-lake biomass estimations (2014-2015) were based upon a total of 7, 70, 7 and 15 biomass samplings, for HOU, LAC, CAZ and PAR respectively. Dense stands of both $E$. densa and L. major were found in LAC and PAR lakes on extended surfaces (about 7 and $13 \%$ of the lake surface, respectively), whereas restricted vegetated areas were observed in $\mathrm{HOU}$ and CAZ lakes, and only by L. major (Tab. 1 and Fig. 3). Both LAC and PAR presented the highest biomass values and coverage for both hydrophytes. Given the presence of only L. major in HOU and CAZ, and given the low occurrence of dense stands in those lakes, we decided to analyse vegetation data and to show results only for LAC and PAR in the next part of this study.
On the whole, the minimum plant colonization depth was $0.4 \mathrm{~m}$, with sparse shoots found at a maximum of 8 $\mathrm{m}$ in LAC. At the lake scale, dense vegetated stands (monospecific + mixed stands) were mainly located at intermediate depths, from 1 to $5 \mathrm{~m}$, with $72 \%$ of vegetated grid cells located between 2 and $4 \mathrm{~m}$ deep (Fig. 4). The main proportion of dense stands $(87 \%$ of vegetated grid cells) was located in areas with sediment resuspension probability minor than $25 \%$. When considering monospecific stands only, it appeared that 2.5-3.5 m was the optimal depth for the development of $E$. densa stands, while L. major seemed to cover indistinctively a large zone situated between 2 and $4 \mathrm{~m}$. In addition, the maximum depth for L. major dense stands was $1 \mathrm{~m}$ greater than for mono-

Tab. 1. Lakes features (http://adour-garonne.eaufrance.fr) and colonized surfaces (expressed in $\mathrm{km}^{2}$ ) and biomass (expressed in tons) by aquatic weeds in French Atlantic Lakes. Total biomass for each lake is calculated on dense stand surfaces only.

\begin{tabular}{|c|c|c|c|c|c|}
\hline & Unit & $\mathrm{HOU}$ & LAC & CAZ & PAR \\
\hline Lake surface & $\mathrm{km}^{2}$ & 57.6 & 16.2 & 48.9 & 31.9 \\
\hline Mean and max depth & $\mathrm{m}$ & 4,15 & 2,7 & 9,24 & 7,22 \\
\hline Secchi depth & $\mathrm{m}$ & $2.1 \pm 0.2$ & $1.9 \pm 0.2$ & $4.6 \pm 0.7$ & $2.3 \pm 0.8$ \\
\hline Sparse shoots $\left(1<\mathrm{x}<50 \mathrm{~g}_{\mathrm{DW}} \mathrm{m}^{-2}\right)$ & $\mathrm{km}^{2}$ & 0.55 & 1.36 & 0.15 & 2.31 \\
\hline Dense stands $\left(\mathrm{x}>50 \mathrm{~g}_{\mathrm{DW}} \mathrm{m}^{-2}\right)$ & $\mathrm{km}^{2}$ & 0.94 & 1.19 & 0.17 & 4.17 \\
\hline \multirow{2}{*}{ L. major monospecific stands } & $\mathrm{km}^{2}$ & 0.94 & 0.37 & 0.17 & 0.81 \\
\hline & tons & 200 & 47 & 45 & 41 \\
\hline \multirow[t]{2}{*}{ E. densa monospecific stands } & $\mathrm{km}^{2}$ & 0.00 & 0.57 & 0.00 & 0.95 \\
\hline & tons & 0 & 270 & 0 & 932 \\
\hline \multirow[t]{2}{*}{ Mixed stands } & $\mathrm{km}^{2}$ & 0.00 & 0.25 & 0.00 & 2.41 \\
\hline & tons & 0 & 83 & 0 & 1812 \\
\hline
\end{tabular}

HOU, Lake Carcans-Hourtin; LAC, Lake Lacanau; CAZ, Lake Cazaux-Sanguinet; PAR, Lake Parentis-Biscarrosse.

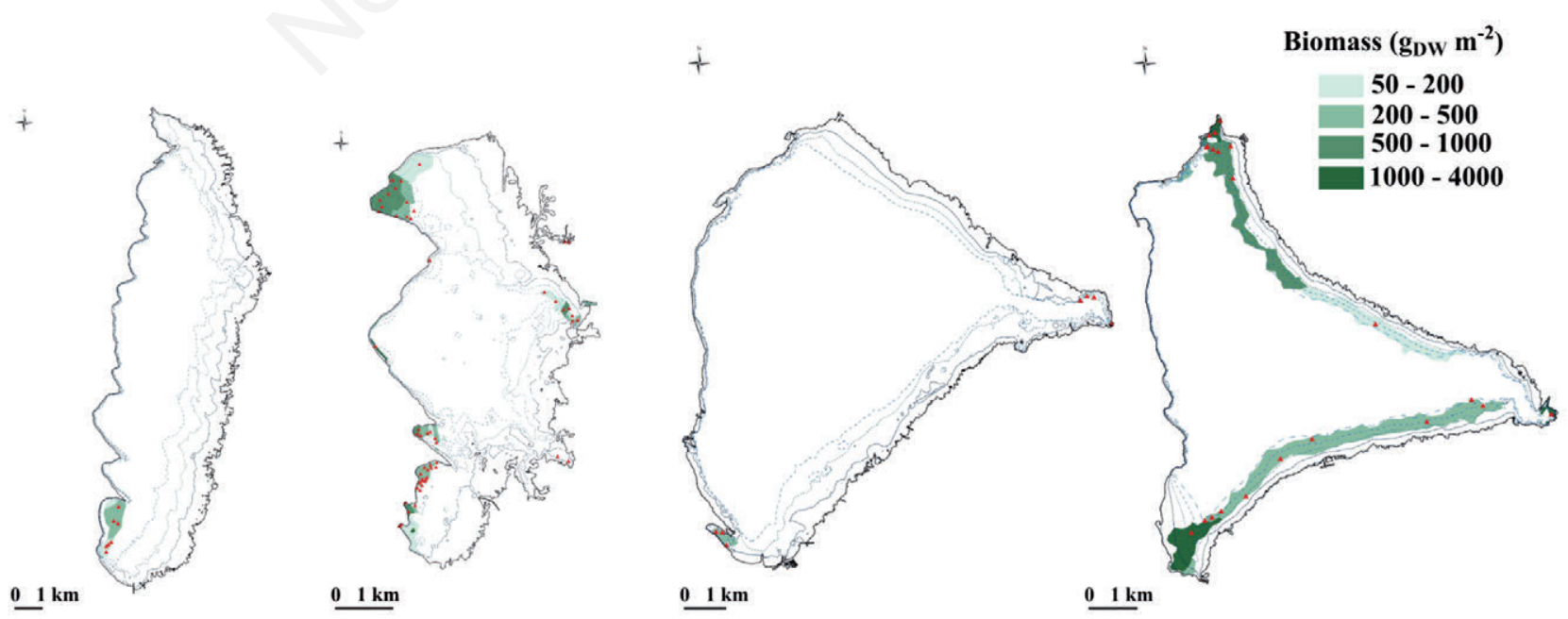

Fig. 3. Distribution and biomass maps of aquatic weeds (E. densa and L. major) obtained by echo-sounding and biomass harvesting in 2014 (HOU and LAC) and 2015 (CAZ and PAR). Triangles indicate biomass harvesting sites; isobaths are reported until $3 \mathrm{~m}$ deep. 
specific $E$. densa stands. With regards to sediment resuspension, the distribution of monospecific $E$. densa stands linearly decreased with the increase of the exposition to water movement, whereas L. major seemed to be less affected by resuspension. Hydrophyte biomass and sedimentary OM content appeared positively correlated at all lakes but one ( $\mathrm{r}$ Pearson=0.62, 0.53 and 0.54 for HOU, $\mathrm{LAC}$ and CAZ, respectively; PAR = not significant).

Biomass, shoot density and morphological traits varied across lakes and species (Tab. 2); E. densa showed significantly higher values than $L$. major for all parameters at both LAC and PAR lakes ( $t$-test, $\mathrm{P}<0.001)$, except
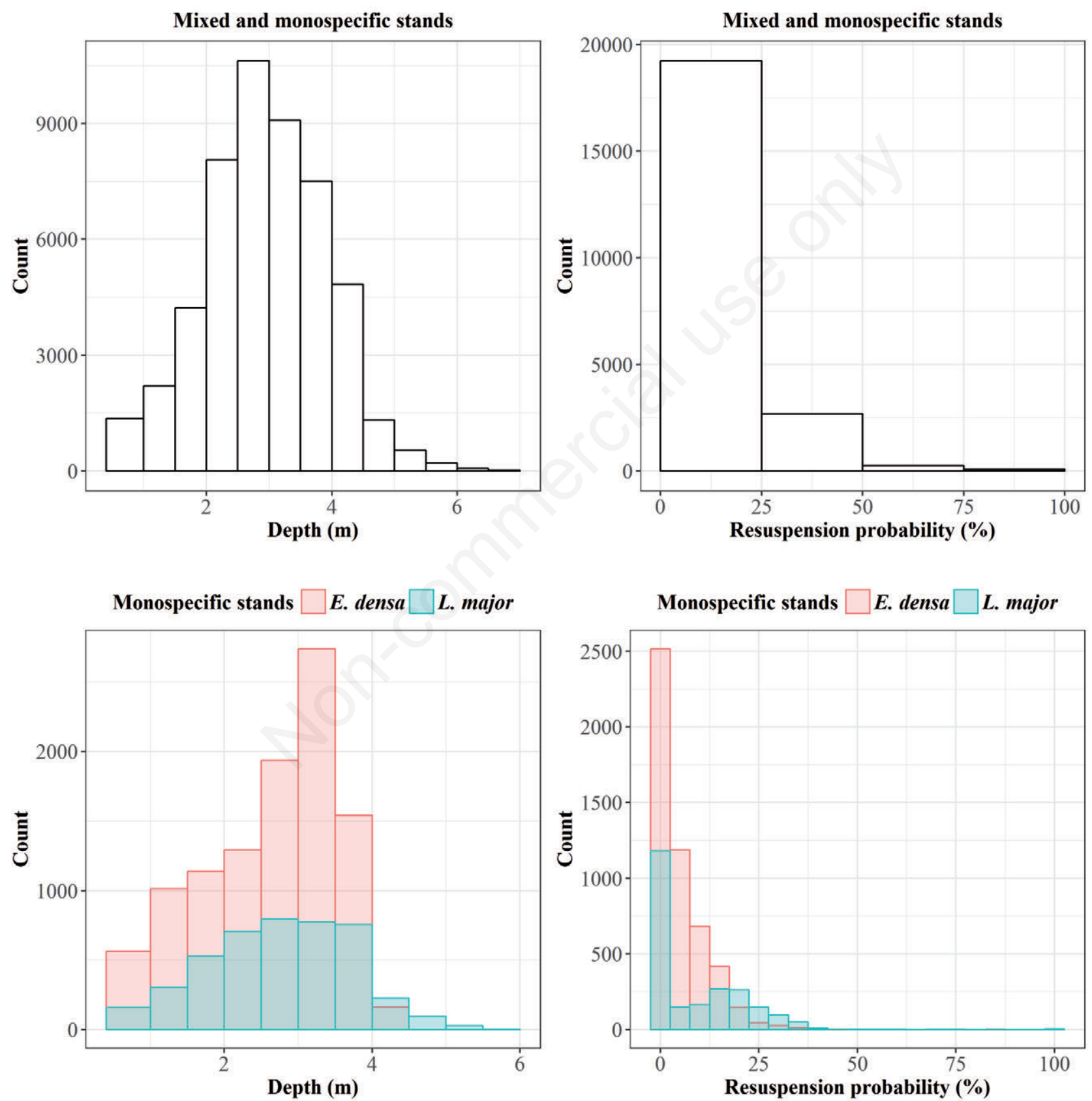

Fig. 4. Occurrence of dense mixed and monospecific stands of two aquatic weeds (L. major and E. densa) according to the depth ( $n=50,029$, on the top left) and resuspension probability ( $n=22,246$, on the top right); occurrence of dense monospecific stands according to the species, the depth $(n=14,769$, on the bottom left) and resuspension probability ( $n=7381$, on the bottom right). Count is based on the occurrence of grid cells corresponding to dense vegetated stands. 
for shoot density at PAR lake. The occurrence of one hydrophyte at elevated density or biomass was inversely correlated to the occurrence of the other one (Fig. 5). Morphological traits in function of sediment resuspension showed different patterns according to the species and the lake (Fig. 6). The influence of resuspension was however not systematic, with many cases where morphological traits were not affected at all. No significant relationship between R:S and resuspension probability was pointed out except in LAC for L. major. In the same way, roots

Tab. 2. Biomass, shoot density and morphological traits measured on Lagaroshiphon major (L. major) and Egeria densa (E. densa) colonizing French Atlantic Lakes. Mean values $\pm \mathrm{SD}$, range values and number of replicates (in square brackets) are reported.

\begin{tabular}{|c|c|c|c|c|c|c|c|c|}
\hline & & Biomass & Shoot density & RA & & MSL & MRL & $R: S$ \\
\hline Lake & & $\left(\mathrm{g}_{\mathrm{DW}} \mathrm{m}^{-2}\right)$ & (shoots $\mathrm{m}^{-2}$ ) & (stems shoot ${ }^{-1}$ ) & $\left(\right.$ roots shoot $\left.{ }^{-1}\right)$ & $(\mathrm{cm})$ & $(\mathrm{cm})$ & \\
\hline $\mathrm{HOU}$ & L. major & $149 \pm 102[7]$ & - & - & - & $72 \pm 27[70]$ & - & $0.01 \pm 0.01[7]$ \\
\hline & & $(88-375)$ & - & - & - & $(32-148)$ & - & $(0.01-0.02)$ \\
\hline & E. densa & 0 & 0 & 0 & 0 & 0 & 0 & 0 \\
\hline & & 0 & 0 & 0 & 0 & 0 & 0 & 0 \\
\hline LAC & L. major & $154 \pm 135[45]$ & $98 \pm 46[32]$ & $2 \pm 1[8]$ & $11 \pm 4[8]$ & $64 \pm 28[202]$ & $33 \pm 7[8]$ & $0.10 \pm 0.09[40]$ \\
\hline & & $(1-1060)$ & $(14-141)$ & $(1-3)$ & $(5-17)$ & $(10-180)$ & $(24-46)$ & $(0.02-0.27)$ \\
\hline & E. densa & $470 \pm 376[76]$ & $189 \pm 136[39]$ & $5 \pm 3[132]$ & $16 \pm 11[116]$ & $102 \pm 38[367]$ & $65 \pm 16[116]$ & $0.13 \pm 0.22[69]$ \\
\hline & & (3-1989) & $(42-594)$ & $(1-15)$ & $(2-56)$ & $(8-236)$ & $(27-98)$ & $(0.01-0.50)$ \\
\hline CAZ & L. major & $154 \pm 106[7]$ & $38 \pm 21$ [7] & $3 \pm 1[13]$ & $14 \pm 10[13]$ & $73 \pm 22[13]$ & $35 \pm 8[13]$ & $0.08 \pm 0.05[7]$ \\
\hline & & $(6-337)$ & $(14-71)$ & $(1-4)$ & $(5-38)$ & $(43-112)$ & $(25-57)$ & $(0.01-0.14)$ \\
\hline & E. densa & 0 & 0 & 0 & 0 & 0 & 0 & 0 \\
\hline & & 0 & 0 & 0 & 0 & 0 & 0 & 0 \\
\hline PAR & L. major & $562 \pm 559[22]$ & $84 \pm 50[17]$ & $3 \pm 1[36]$ & $10 \pm 7[21]$ & $137 \pm 54[51]$ & $29 \pm 11[22]$ & $0.03 \pm 0.02[16]$ \\
\hline & & $(1-1505)$ & $(14-184)$ & $(1-5)$ & (3-39) & $(43-255)$ & $(8-57)$ & $(0.01-0.08)$ \\
\hline & E. densa & $1942 \pm 1820[35]$ & $127 \pm 102[32]$ & $4 \pm 3[133]$ & $16 \pm 14[64]$ & $205 \pm 65[119]$ & $52 \pm 22[76]$ & $0.06 \pm 0.04[32]$ \\
\hline & & $(6-6177)$ & $(14-340)$ & $(1-17)$ & $(1-77)$ & $(41-321)$ & $(9-102)$ & $(0.01-0.09)$ \\
\hline
\end{tabular}

RAM, ramifications; MSL, max stem length; MRL, max root length; $R: S$, root to shoot ration; HOU, Lake Carcans-Hourtin; LAC, Lake Lacanau; CAZ, Lake Cazaux-Sanguinet; PAR, Lake Parentis-Biscarrosse.
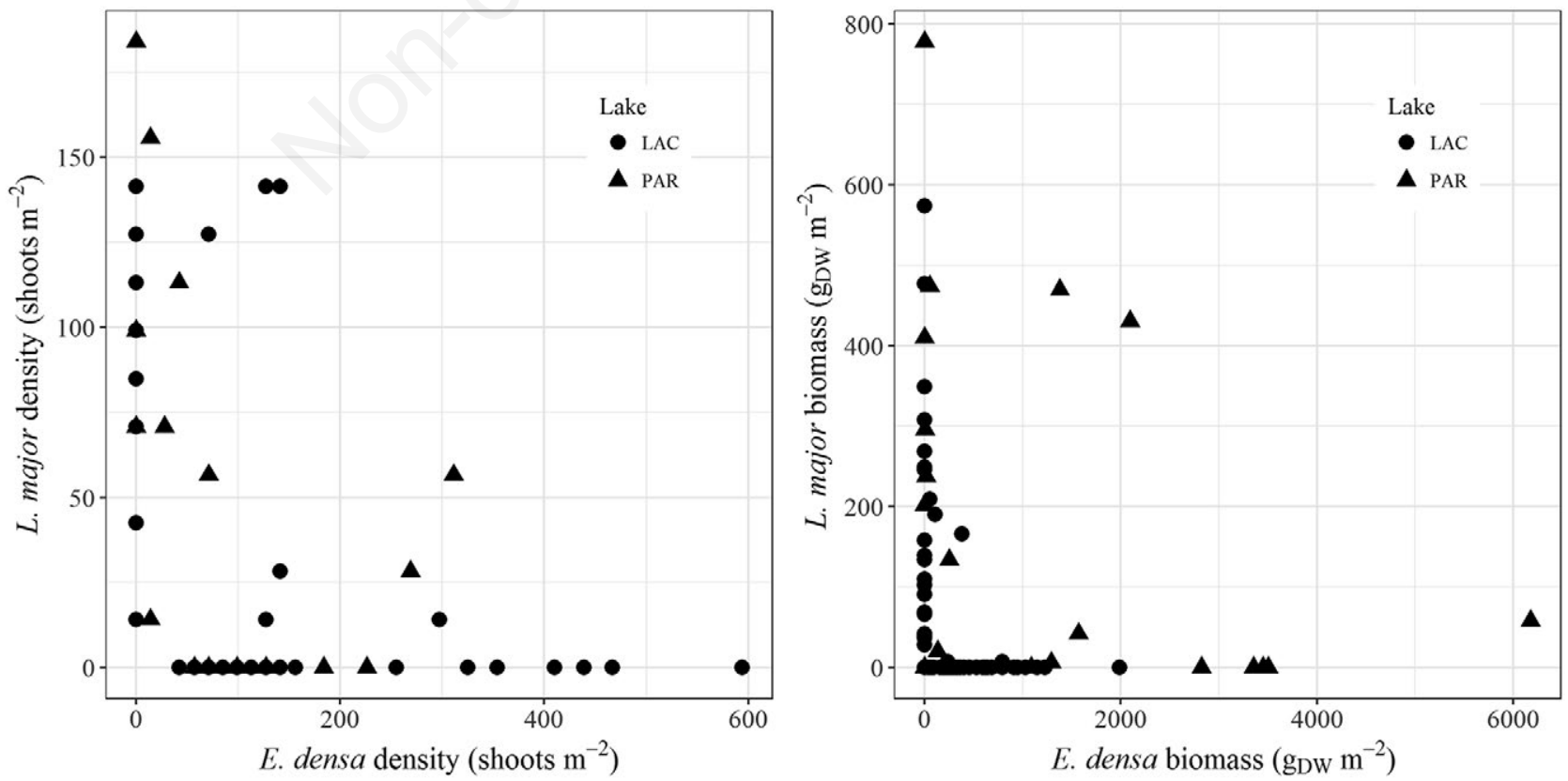

Fig. 5. Relation between the density (on the left) and the biomass (on the right) of the two hydrophytes L. major and E. densa. 
length significantly decreased in PAR for E. densa when resuspension probability increased $\left(\mathrm{F}_{1,74}, \mathrm{R}^{2}=0.12\right.$, $\mathrm{P}<0.01)$. No significant relationship was evidenced between density and resuspension probability at all lakes. The parameter appearing to best respond to the impact of sediment resuspension was the maximum stem length, which was significantly higher for both species in PAR, while it was not correlated for L. major in LAC.

\section{DISCUSSION}

\section{Plant distribution}

This study documents the massive presence of two rooted aquatic weeds in French Atlantic Lakes. E. densa and L. major formed extensive dense stands (up to 4.17 $\mathrm{km}^{2}$ ), with standing crops varying from 45 to 2785 tons of dry biomass per lake (from 0.05 to $6.18 \mathrm{~kg}_{\mathrm{DW}} \mathrm{m}^{-2}$ ), which covered from 1.6 to $13.0 \%$ of the total surface of the lakes. In many areas, plant biomass and vegetated patches largely overpassed values reported for invasive free-floating plants (up to $2.5 \mathrm{~kg}_{\mathrm{DW}} \mathrm{m}^{-2}$ and $2 \mathrm{~km}^{2}$ ) (Center and Spencer, 1981; Nieder et al., 2004). Though echosounding surveys did not allow prospecting the full lake surface, it resulted to be a reliable method for delimiting the stand boundaries (Wells et al., 1997; Zajac, 2008). We acknowledge that some portions of the lakes where sparse shoots exist could not be included in this survey; for this reason, the lake-scaled biomass estimation only refers to dense stands. Also, interannual variability in biomass might have affected our evaluation; anyway, our results highlight the magnitude of the plant colonization and constitute a first biomass assessment.

When looking at the comparison between the two hydrophytes, E. densa appeared to be a major potential threat when compared to L. major, both in terms of biomass and density. Indeed, while L. major maximum stem length and biomass resulted similar or even lower than those reported in other studies and other sites (Clayton, 1982; Dutartre and Oyarzabal, 1993; Wells et al., 1997; Bickel and Closs, 2008), the opposite happened for $E$. densa biomass, which reached much higher values (maximum $6.2 \mathrm{~kg}_{\mathrm{DW}} \mathrm{m}^{-2}$ in PAR) than those reported in tropical waters (maximum $0.5 \mathrm{~kg}_{\mathrm{DW}} \mathrm{m}^{-2}$ and $1.2 \mathrm{~kg}_{\mathrm{DW}} \mathrm{m}^{-2}$ in South-American reservoirs) (Pelicice et al., 2005; Carrillo et al., 2006).

Both L. major and E. densa appeared to be able to colonize the whole range of depth in French Atlantic Lakes, until $8 \mathrm{~m}$ deep for sparse shoots, corresponding to the maximum depths observed in tropical and not light-limited environments (Coffey and Wah, 1988; Carrillo et al., 2006). Dense stands however preferentially developed between 2 and $4 \mathrm{~m}$ deep, showing a possible interplay between light availability and hydrodynamics preferences. Indeed, the majority of the dense stands were located at low sediment resuspension areas, which indicates that calm waters constitute a preferential habitat for dense mats development. However, even areas characterized by low to medium sediment resuspension (10-45\%) were colonized by an elevated plant density.

The depth zonation of the two hydrophytes did not result as distinct as in other studies on native species, which showed that different species of Potamogeton can occupy distinct colonization depth within one lake (Lehmann et al., 1997). Nevertheless, our survey showed that the two hydrophytes rarely occur together at elevated biomass or density. On the whole, our results show that E. densa and L. major prefer deep-sheltered areas in Atlantic shallow lakes, with a tendency for L. major to colonize deeper and more exposed areas than E. densa. This result is in line to
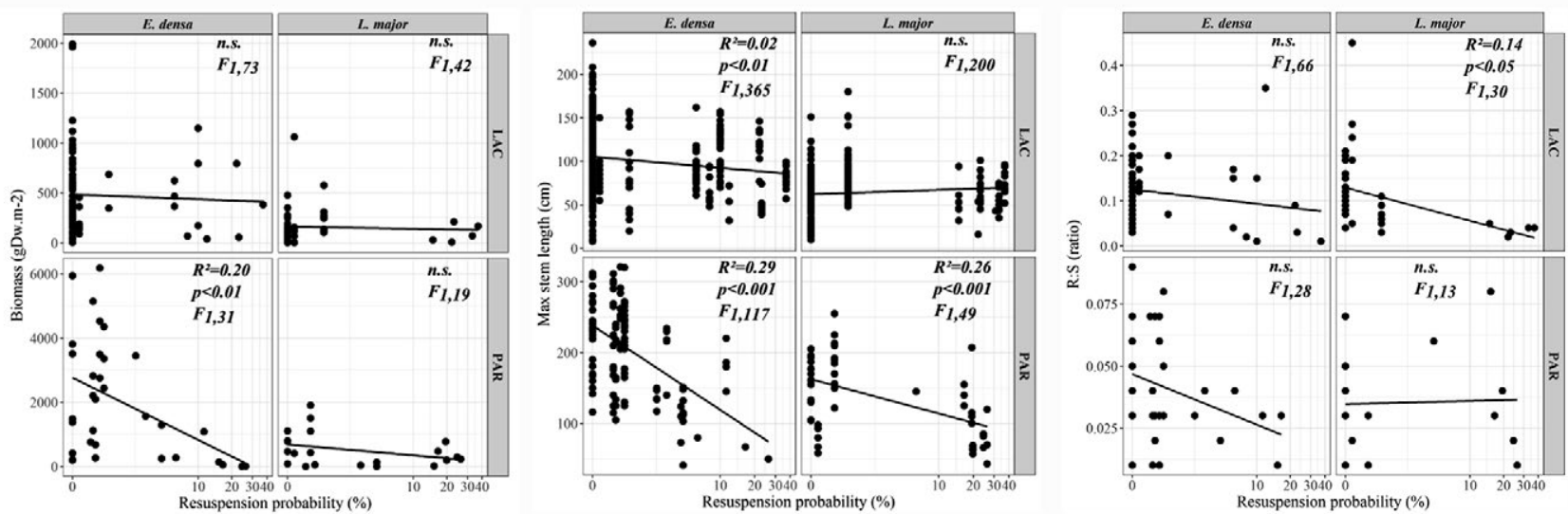

Fig. 6. Relation between the biomass (on the left), maximum stem length (on the middle) and root to shoot ratio (on the right) of the two hydrophytes L. major and E. densa. 
what Ellawala et al. (2011) and Riis et al. (2012) found in experimental conditions and highlights a speciesspecific response to hydrodynamic forces.

\section{Plants morphological traits and hydrodynamics}

Both $E$. densa and L. major produce dense canopies with long stems (maximum $321 \mathrm{~cm}$ for $E$. densa in PAR), which drag at the water surface during summer period. This type of vegetative development could reduce wave tolerance, increasing plant breakage and morphology modifications, unlike meadow-forming species which lie closer to the sediment surface when the current velocity is elevated (Koch, 2001). The response of morphological traits to sediment resuspension here reported matches indeed with investigations previously carried out on $E$. densa (Ellawala et al., 2011) and other hydrophytes such as Myriophyllum spicatum L. (Strand and Weisner, 2001) and Vallisneria spiralis L. (Doyle, 2001) in experimental conditions. Anyway, the relationships we found were not systematic and often lake-dependent and species-specific. These results in general did not confirm our initial hypotheses. An increase of the root length would have been expected with the increase of sediment resuspension, as a phenotypic adaptation for assuring a better anchorage to the plant. Other studies report that belowground biomass plasticity according to wave exposure and sediment granulometry has been found to be often inconsistent (Koch, 2001). Moreover, no relationship was observed in some morphological traits such as the number of stems and roots per shoot. Different responses of the relationship traits-hydrodynamics can be attributable to the different lake sizes. PAR lake surface is two times larger than LAC; as a consequence, the fetch lengths are potentially higher in PAR than in LAC. The orbital velocity of waves is function of the wind direction and velocity, and also depends on the fetch length required to calculate the wave height, length and period (Rohweder et al., 2012). Even if the resuspension probability is always binary $(1=$ resuspension, or $0=$ no resuspension) and identifies the occurrence of a disturbance, it does not give the intensity of the force induced by waves. Wave disturbance in PAR has probably a more important impact on plant morphological features, as reported by some authors for large lakes (Schneider et al., 2015; Schutten et al., 2004). In further research, it would be thus interesting to include the maximum orbital velocity in the model.

\section{Aquatic weeds as species engineers}

Our research highlights the importance that dense vegetated stands take on in shallow lakes productivity. French Atlantic Lakes are characterized by slow-growing vegetation typical of acidic conditions and by low pelagic production (Cellamare et al., 2012; Ribaudo et al., 2017). If we assume a carbon content of $39.5 \%$ in plant tissues (Carvalho et al., 2005) and consider the total measured biomass and the colonized surface on the four lakes, we can estimate that those two hydrophytes may fix from 84 to $264 \mathrm{~g} \mathrm{C} \mathrm{m}^{-2}$ (for HOU and PAR lakes, respectively). This value is comparable to the $C$ sequestration capacity of other hydrophytes of the same lakes (Ribaudo et al., 2017), yet the proportion of vegetated areas is much different. Indeed, when considering the colonized areas by $E$. densa and L. major, we can estimate a productivity ranging between 18 and 1100 tons of $\mathrm{C} \mathrm{lake}^{-1}$ at their standing crop (for CAZ and PAR lakes, respectively). This budget lacks, however, of the assessment of the carbon release due to respiration processes in dense vegetated stands at the lake scale. A definitive assessment of the net ecosystem metabolism would take into account the quota of carbon decomposed and released in situ at the senescence of the plants, that having potential cascading effects on local oxygenation and on the enhancement of anaerobic processes such as methanogenesis (Cunha-Santino and Bianchini, 2004; Carvalho et al., 2005; Urban et al., 2009; Ribaudo et al., 2014).

E. densa and L. major are two rooted hydrophytes able to grow on a wide spectrum of substrata and depths (Riis et al., 2010), commonly found on silty, mesotrophic sediments (Bini et al., 1999; Martin and Coetzee, 2014; Matsui, 2014). As a consequence, we would not expect to find dense stands on very organic-poor sediments $(<0.3 \%$ as LOI, at PAR lake). We can hypothesize that we are dealing with an initial phase of the settlement, where the barrier formed by elevated shoot densities possibly triggers a positive feedback on water flow decrease and favors fine particles sedimentation (Barko et al., 1991; Madsen et al., 2001). We found indeed a significant correlation between the quantity of biomass and the degree of OM content, that indicating an interaction between a substrate preference by the plant and the effect of the canopy on fine particles sedimentation. Here, the release of nutrients from fluffy sediments likely contributes to sustain plant growth under oligotrophic conditions (Anderson and Kalff, 1986; Bolpagni et al., 2015). An aliquot of the organic matter produced in dense stands may be transferred to deeper layers of the lakes and support oxidative degradation (Siffedine et al., 2011).

\section{Implication for management purposes and biomonitoring}

The recreational use of French Atlantic Lakes for touristic purposes has historically matched with a management aiming at a low environmental impact (Ghelardoni, 1990). Recently, negative human perception increased against aquatic weeds, due to a spread of lake's recreational uses (sealing, motor boating, hunting and fishing). Concurrently, those activities have a probable positive feedback on the 
settlement of the two non-native hydrophytes through fragments dispersal (Bruckerhoff et al., 2015). Management actions for removing biomass from harbours accounted for several tens of thousands euros between 2010 and 2015 (SIAEBVELG and Géolandes local authorities); those actions were, however, spatially restrained in order to limit negative impacts caused by nutrients regeneration from sediments (van Nes et al., 2002).

\section{CONCLUSIONS}

Our study assesses the current distribution of two aquatic weeds in French Atlantic Lakes, that making easier for managers to plan harvesting interventions. In addition, as we highlighted the link between plant distribution and sediment resuspension, we alert to the risks induced by the creation of artificial calm-water zones (e.g., marinas, harbours, canalizations) that could favour the onset of dense stands. Taking into account artificial hydromorphologic modifications would be convenient for improving biomonitoring approaches, which are at present focused on the detection of nutrient and organic pollution only (Kolada et $a l ., 2014)$. Our results could be also used to identify suitable areas for potential colonization by $E$. densa, which is still currently not present in two of the four lakes. Both lakes HOU and CAZ are highly vulnerable to be colonized by $E$. densa in the near future, due to their accessibility to human activities through the presence of public boat launches and some navigation ways linking the lakes. Beyond the capacity of predicting the occurrence of invasive organisms at a multiple-systems scale, we believe that it is now necessary to inform managers on the potential distribution of a likely new invasive plant at the local scale (e.g., lake or a specific part of a lake) in order to help them in management decision.

\section{ACKNOWLEDGMENTS}

Authors sincerely thank A. Dutartre (Agence Régionale pour la Biodiversité Aquitaine), S. Morin and J. Rosebery for supporting the study. S. Moreira, A. Caro, T. Huguet, H. Guerreiro, A. Poli, J. Chabanne and J. Keller contributed to field and data treatment. We are thankful to Frank Quenault (SIAEBVELG) and Andoni Zuazo (Géolandes) for supplementary information on local plants management. This work was mainly funded by AEAG (Agence de l'Eau Adour-Garonne), by Irstea (Institut de Recherche Sciences et Technologies pour l'Environnement et l'Agriculture) and partly by the Conseil Régional Nouvelle Aquitaine within the AquaVIT and CLAQH projects. Wind data were provided by Météo France. All authors declare that they have no conflict of interest.

\section{REFERENCES}

Anderson MR, Kalff J, 1986. Regulation of submerged aquatic plant distribution in a uniform area of a weedbed. J. Ecol. 4:953-961.

Barko JW, Gunnison D, Carpenter SR, 1991. Sediment interactions with submersed macrophyte growth and community dynamics. Aquat. Bot. 41:41-65.

Barrat-Segretain MH, 2001. Biomass allocation in three macrophyte species in relation to the disturbance level of their habitat. Freshwater Biol. 46:935-945.

Bertrin V, Boutry S, Dutartre A, Lambert E, 2013. [Communautés de Characées des lacs médocains (Sud-Ouest de la France). Eléments d'écologie et de distribution].[Article in French]. Acta Bot. Gallica. 160:131-140.

Bickel TO, Closs GP, 2008. Fish distribution and diet in relation to the invasive macrophyte Lagarosiphon major in the littoral zone of Lake Dunstan, New Zealand. Ecol. Freshw. Fish. 17:10-19.

Bini LM, Thomaz SM, 2005. Prediction of Egeria najas and Egeria densa occurrence in a large subtropical reservoir (Itaipu Reservoir, Brazil-Paraguay). Aquat. Bot. 83: 227-238.

Bini LM, Thomaz SM, Murphy KJ, Camargo AF, 1999. Aquatic macrophyte distribution in relation to water and sediment conditions in the Itaipu Reservoir, Brazil. Hydrobiologia 415:147-154.

Bolpagni R, Laini A, Soana E, Tomaselli M, Nascimbene J, 2015. Growth performance of Vallisneria spiralis under oligotrophic conditions supports its potential invasiveness in mid-elevation freshwaters. Weed Res. 55:185-194.

Bornette G, Puijalon S, 2011. Response of aquatic plants to abiotic factors: a review. Aquat. Sci. 73:1-14.

Bruckerhoff L, Havel J, Knight S, 2015. Survival of invasive aquatic plants after air exposure and implications for dispersal by recreational boats. Hydrobiologia. 746:113-121.

Brundu G, 2015. Plant invaders in European and Mediterranean inland waters: profiles, distribution, and threats. Hydrobiologia 746:61-79.

Carrillo Y, Guarín A, Guillot G, 2006. Biomass distribution, growth and decay of Egeria densa in a tropical high-mountain reservoir (NEUSA, Colombia). Aquat. Bot. 85:7-15.

Carvalho P, Thomaz SM, Bini LM, 2005. Effects of temperature on decomposition of a potential nuisance species: the submerged aquatic macrophyte Egeria najas Planchon (Hydrocharitaceae). Braz. J. Biol. 65:51-60.

Celesti-Grapow L, Alessandrini A, Arrigoni PV et al., 2010. Non-native flora of Italy: Species distribution and threats. Plant Biosyst. 144:12-28.

Cellamare M, Morin S, Coste M, Haury J, 2012. Ecological assessment of French Atlantic lakes based on phytoplankton, phytobenthos and macrophytes. Environ. Monit. Assess. 184:685-708.

Center TD, Spencer NR, 1981. The phenology and growth of water hyacinth (Eichhornia crassipes (Mart.) Solms) in a eutrophic north-central Florida lake. Aquat. Bot. 10:1-32.

Chambers PA, 1987. Nearshore occurrence of submersed aquatic macrophytes in relation to wave action. Can. J. Fish. Aquat. Sci. 44:1666-1669.

Chambers PA, Prepas EE, Hamilton HR, Bothwell ML, 1991. 
Current velocity and its effect on aquatic macrophytes in flowing waters. Ecol. Appl. 1:249-257.

Clayton JS, 1982. Effects of fluctuations in water level and growth of Lagarosiphon major on the aquatic vascular plants in Lake Rotoma, 1973-80. New Zeal. J. Mar. Fresh. 16:89-94.

Coffey B, Wah CK, 1988. Pressure inhibition of anchorage-root production in Lagarosiphon major (Ridl.) Moss: a possible determinant of its depth range. Aquat. Bot. 29:289-301.

Cunha-Santino MB, Bianchini Jr I, 2004. Oxygen uptake during mineralization of humic substances from Infernão Lagoon (São Paulo, Brazil). Braz. J. Biol. 64:583-590.

Doyle RD, 2001. Effects of waves on the early growth of Vallisneria americana. Freshwater Biol. 46:389-397.

Dutartre A, Capdevielle P, 1982. [Répartition actuelle de quelques végétaux vasculaires aquatiques introduits dans le Sud-Ouest de la France].[Article in French], p. 390-393. In: J.J. Symoens, S.S. Hooper and P. Compère (eds.), Studies on Aquatic vascular plants. Royal Botanical Society of Belgium.

Dutartre A, Oyarzabal J, 1993. [Gestion des plantes aquatiques dans les lacs et les étangs landais].[Article in French]. Hydroécol. Appl. 5:43-60.

Dutartre A, Haury J, Jigorel A, 1999. Succession of Egeria densa in a drinking water reservoir in Morbihan (France), p. 243247. In: J. Caffrey, P.R.F. Barrett, M.T. Ferreira, I.S. Moreira, K.J. Murphy and P.M. Wade (eds.), Biology, ecology and management of aquatic plants: Proceedings 10th Int. Symp. on Aquatic Weeds, European Weed Research Society.

Ellawala KC, Asaeda T, Kawamura K, 2011. The effect of flow turbulence on plant growth and several growth regulators in Egeria densa Planchon. Flora 206:1085-1091.

Foote AL, Kadlec JA, 1988. Effects of Wave Energy on Plant Establishment in Shallow Lacustrine Wetlands. J. Freshwater Ecol. 4:523-532.

Ghelardoni P, 1990. Tourist planning along the coast of Aquitaine, France, p. 191-197. In: P. Fabbri (ed.) Recreational uses of coastal areas. The Geojournal Library.

Hussner A, 2012. Alien aquatic plant species in European countries. Weed Res. 52:297-306.

Johnson JA, Newman RM, 2011. A comparison of two methods for sampling biomass of aquatic plants. J. Aquat. Plant Manage. 49:1-8.

Keddy PA, 1982. Quantifying within-lake gradients of wave energy: interrelationships of wave energy, substrate particle size and shoreline plants in axe lake, Ontario. Aquat. Bot. 14:41-58.

Koch EW, 2001. Beyond light: physical, geological, and geochemical parameters as possible submersed aquatic vegetation habitat requirements. Estuaries 24:1-17.

Kolada A, Willby N, Dudley B, Nõges P, Søndergaard M, Hellsten S, Mjelde M, Penning E, van Geest G, Bertrin V, Ecke F, Mäemets H, Karus K, 2014. The applicability of macrophyte compositional metrics for assessing eutrophication in European lakes. Ecol. Indic. 45:407-415.

Lehmann A, Castella E, Lachavanne JB, 1997. Morphological traits and spatial heterogeneity of aquatic plants along sediment and depth gradients, Lake Geneva, Switzerland. Aquat. Bot. 55:281-299.

Madsen JD, Chambers PA, James WF, Koch EW, Westlake DF, 2001. The interaction between water movement, sediment dynamics and submersed macrophytes. Hydrobiologia 444:71-84.

Martin GD, Coetzee JA, 2014. Competition between two aquatic macrophytes, Lagarosiphon major (Ridley) Moss (Hydrocharitaceae) and Myriophyllum spicatum Linnaeus (Haloragaceae) as influenced by substrate sediment and nutrients. Aquat. Bot. 114:1-11.

Matsui A, 2014. Relationship between distribution and bottom sediment of submerged macrophytes in the Seta River, Shiga Prefecture, Japan. Landsc. Ecol. Eng. 10:109-113.

Nieder WC, Barnaba E, Findlay SE, Hoskins S, Holochuck N, Blair EA, 2004. Distribution and abundance of submerged aquatic vegetation and Trapa natans in the Hudson River Estuary. J. Coastal Res. 45:150-161.

Pelicice FM, Agostinho AA, Thomaz SM, 2005. Fish assemblages associated with Egeria in a tropical reservoir: investigating the effects of plant biomass and diel period. Acta Oecol. 27:9-16.

Puijalon S, Léna JP, Rivière N, Champagne JY, Rostan JC, Bornette G, 2008. Phenotypic plasticity in response to mechanical stress: hydrodynamic performance and fitness of four aquatic plant species. New Phytol. 177:907-917.

Redekop P, Hofstra D, Hussner A, 2016. Elodea canadensis shows a higher dispersal capacity via fragmentation than Egeria densa and Lagarosiphon major. Aquat. Bot. 130:45-49.

Ribaudo C, Bertrin V, Dutartre A, 2014. Dissolved gas and nutrient dynamics within an Egeria densa Planch. bed. Acta Bot. Gallica. 161:233-241.

Ribaudo C, Bertrin V, Jan G, Anschutz P, Abril G, 2017. Benthic production, respiration and methane oxidation in Lobelia dortmanna lawns. Hydrobiologia. 784:21-34.

Riis T, Hawes I, 2003. Effect of wave exposure on vegetation abundance, richness and depth distribution of shallow water plants in a New Zealand lake. Freshwater Biol. 48:75-87.

Riis T, Olesen B, Clayton JS, Lambertini C, Brix H, Sorrell BK, 2012. Growth and morphology in relation to temperature and light availability during the establishment of three invasive aquatic plant species. Aquat. Bot. 102:56-64.

Rohweder J, Rogala JT, Johnson BL, Anderson D, Clark S, Chamberlin F, Runyon K, 2012. Application of wind fetch and wave models for habitat rehabilitation and enhancement projects - 2012 Update. U.S. Geological Survey Open-File Report 2008-1200, 43pp.

Sand-Jensen K, 2003. Drag and reconfiguration of freshwater macrophytes. Freshwater Biol. 48:271-283.

Schneider B, Cunha ER, Marchese M, Thomaz SM, 2015. Explanatory variables associated with diversity and composition of aquatic macrophytes in a large subtropical river floodplain. Aquat. Bot. 121:67-75.

Schutten J, Dainty J, Davy A, 2004. Wave-induced hydraulic forces on submerged aquatic plants in shallow lakes. Ann. Bot. London. 93:333-341.

Schutten J, Dainty J, Davy A, 2005. Root anchorage and its significance for submerged plants in shallow lakes. J. Ecol. 93:556-571.

Sifeddine A, Meyers PA, Cordeiro RC et al., 2011. Delivery and deposition of organic matter in surface sediments of Lagoa do Caçó (Brazil). J. Paleolimnol. 45:385-396.

Strand J, Weisner SB, 1996. Wave exposure related growth of epi- 
phyton: implications for the distribution of submerged macrophytes in eutrophic lakes. Hydrobiologia 325:113-119.

Strand J, Weisner SB, 2001. Morphological plastic responses to water depth and wave exposure in an aquatic plant (Myriophyllum spicatum). J. Ecol. 89:166-175.

Tastet JP, Lalanne R, Maurin B, Dubos B, 2008. Geological and archaeological chronology of a late Holocene coastal enclosure: The Sanguinet lake (SW France). Geoarchaeology 23:131-149.

Urban RA, Titus JE, Zhu WX, 2009. Shading by an invasive macrophyte has cascading effects on sediment chemistry. Biol. Invasions 11:265-273.

Van Nes EH, Scheffer M, Van Den Berg MS, Coops H, 2002.
Aquatic macrophytes: restore, eradicate or is there a compromise? Aquat. Bot. 72:387-403.

Wells RD, De Winton MD, Clayton JS, 1997. Successive macrophyte invasions within the submerged flora of Lake Tarawera, central North Island, New Zealand. New Zeal. J. Mar. Fresh. 31:449-459.

Yarrow M, Marin VIH, Finlayson M, Tironi A, Delgado LE, Fischer F, et al., 2009. The ecology of Egeria densa Planchon (Liliopsida: Alismatales): A wetland ecosystem engineer. Rev. Chil. Hist. Nat. 82:299-313.

Zajac RN, 2008. Challenges in marine, soft-sediment benthoscape ecology. Landscape Ecol. 23:7-18. 